EKSAKTA Vol. 12 No. 1, 26-31

\title{
Effect Of Curcumin And Honey To Pharmacokinetics Of Paracetamol In Male Wistar Rats
}

\author{
Dimas Adhi Pradana, Farida Hayati, Agung Giri Samudra, Amalinda Setya \\ Kartika \\ Prodi Farmasi FMIPA Universitas Islam Indonesia, Yogyakarta \\ email : adhi_pradana85@yahoo.com
}

\begin{abstract}
Honey and curcumin is widely consumed by children as food supplements. Honey is useful as an antioxidant and antibacterial, while curcumin is useful as an antioxidant, antiinflammatory, antibacterial, antiviral. Both health supplements are not infrequently used in conjunction with drugs, especially paracetamol. This study aims to determine the effect of curcumin and honey on the pharmacokinetic parameters of paracetamol in male rats. In this study, test animals were divided into 3 groups: control, treatment I and treatment II. In the control group mice were given paracetamol 150mg / KgBW, treatment group I rats were given curcumin $18 \mathrm{mg} / \mathrm{KgBW}, 1$ hour and then given paracetamol $150 \mathrm{mg} / \mathrm{KgBW}$ whereas the treatment group II rats given a dose of honey $7.65 \mathrm{~mL} / \mathrm{KgBW}$ along with giving paracetamol 150mg KgBB . The results showed that administration of curcumin on the pharmacokinetics of paracetamol in mice can decrease the primary parameters of the elimination phase of $\mathrm{CL}_{\mathrm{T}}$ for $68.25 \%$, increasing the secondary parameter $\mathrm{t}_{1 / 2}$ at $193.72 \%$, thus increasing the derivative parameters $\mathrm{AUC}_{0 \text {-inf }}$ for $88.36 \%$, and MRT of $155.17 \%(\mathrm{p}<0.05)$. Giving qualitatively honey can inhibit the absorption process of paracetamol in male rats.
\end{abstract}

Keyewords: Curcumin, honey, paracetamol, pharmacokinetic parameter 